\title{
The Breakthrough: Polish elections in June 1989
}

\author{
JAN PAKULSKI
}

History needs a broad perspective and it is most clear when aided by hindsight and long distance. The 20 years that have just passed since the memorable June of 1989 provide a most useful platform for assessing the historical importance of the three events in Poland that constituted the political 'Breakthrough': the round table negotiations in February-April 1989, the 'contract' parliamentary elections in June, and the formation of the Solidarity government in September 1989 - the first non-communist government in the Soviet Bloc. Together, in a spiralling and self-reinforcing political sequence, they formed a 'Breakthrough', that is, a threefold shift: for Solidarity, a shift from (predominantly moral) opposition to (politically constructive) affirmation; for Polish political leaders, a shift from reforms of the communist system to systemic transformation 'out of the system'; and for Eastern Europe, a shift from dissent to a phase of institutional change into 'post-communism'. In other words, the three events, as claimed here, played a crucial role in accelerating and radicalising the 'internal' socio-political developments in Poland-transforming Solidarity opposition into Solidarity government - and 'externally', in the entire region, by starting a political 'contagion' that led to the domino-like collapse of communist regimes all over Eastern Europe.

The Breakthrough itself, as argued in the Introduction and by this author elsewhere in this volume (Chapter 6), has to be historically 'embedded'. For a start, it has to be seen within the historical sequence of events that generated the annus mirabilis in Europe: the economic crisis of Soviet-type socialism as reflected in deepening economic woes and widening political dissent; the evolution of social protests and upheavals, especially under the impact of 'cumulative learning' and influential appeals of the Polish Pope, both pushing the communist authorities to negotiations with the democratic opposition; Gorbachev's perestroika and glasnost, which gave an 'amber light' of cautious approval to all Eastern European reformists; the accompanying climate of West- 
East détente that enabled the largely peaceful transformations; and, last but not least, the mass media revolution and the 'global village' effect that facilitated the political contagion.

This broader historical framework is outlined in more detail in Chapter 6 of this volume. Here, we look only at key events in Poland most directly linked with, and leading to, the Solidarity-engineered Breakthrough, as well as the impact of this Breakthrough on developments in the region.

\section{The Background}

The round table has a relatively short history. While the very idea of negotiated conflict resolution and political compromise was popular in opposition circles in the 1970s and 1980s, and had already been applied during the negotiations in August-September 1980 that led to the formation of Solidarity, the label itself was popularised by General Jaruzelski in mid-1988, when he proposed reconciliation talks aimed at defusing the mounting social unrest caused by the failure of martial law to 'close the Solidarity chapter'. Attempts at reforming the ailing Polish economy 'from above', without a broader social compact, proved unsuccessful, and, by the late 1980s, the communist authorities started to realise that negotiations with the opposition were unavoidable.

This realisation was also prompted by a new political climate created by Gorbachev's reforms and the accompanying climate of détente with the West. The unexpected developments in Moscow were initially treated with suspicion. But the sceptics were proven wrong, in particular after Gorbachev's tolerant treatment of Soviet dissenters, especially Sakharov; his unexpected renunciation of 'Brezhnev's Doctrine' at the UN forum in 1988; and his friendly gestures towards the West. Even the harshest sceptics in Poland changed their views after Gorbachev's friendly meetings with opposition intellectuals during his visit to Poland in summer 1988, in the midst of the second strike wave that prompted General Jaruzelski to offer round table talks. The Soviet leader made it clear to the Polish authorities that any form of violent suppression of the opposition would not be approved in Moscow. This message was reinforced by the Catholic Church hierarchy and the Pope, both of whom stressed the need for 'social dialogue'. Similarly, Western leaders, especially George Bush, Margaret Thatcher and François Mitterrand, made peaceful negotiations with the opposition the first condition of granting Poland the desperately needed economic aid.

Thus, in mid-1988, after eight years of stubborn resistance to any idea of negotiating with Solidarity, the communist authorities in Poland started to budge. The push came mainly from the deepening economic crisis. By the 
end of 1988, the Polish economy was again in freefall, and the reforms of the old centrally managed system of government did not progress beyond some superficial 'public-private' ventures - widely seen as transfers of profitable public property into the hands of the party nomenklatura. In a then popular phrase, the 1980s had proven to be a 'lost decade' - a prolonged political stalemate amidst growing social frustration and helplessness. Faced also with the winds of change blowing through Moscow and widening social unrest, General Jaruzelski, and his closest advisors, including the Security Chief, General Czesław Kiszczak, decided to offer an olive branch to the opposition by agreeing to open round table talks with leaders of all political forces, including Solidarity. ${ }^{1}$ They also enrolled the assistance of the Catholic Church, whose Episcopate provided observers during the negotiations. After some hitches and delays, the keenly awaited round table negotiations started in February 1989.

They started in an atmosphere of suspicion and panic. Poland was, again, a rumbling social volcano ready to erupt. The Polish economy was grinding to a halt under the burden of mismanagement, mounting debt, galloping inflation, and multiplying strikes. Inflation was approaching 100 per cent. In January 1989, there were 49 strikes with an estimated 15000 participants; in February, there were 67 strikes involving more than 60000 workers; in March, the authorities registered 260 strikes - most of them spontaneous and only 3 per cent of them organised by Solidarity. ${ }^{2}$ The crisis was exacerbated by political divisions within the communist camp. While Jaruzelski, Kiszczak and a handful of their backers saw the proverbial 'writing on the wall', the majority of the communist nomenklatura, as well as the leaders of the government-controlled unions (OPZZ), were suspicious of negotiations and opposed lifting the ban on Solidarity. Their fear of the free unions combined with loathing for Lech Wałęsa - who became the most media-vilified person in Poland in the 1980s were as strong as their fear of social unrest. There was a good chance that these political tensions would derail the round table and lead to another violent confrontation.

The situation changed gradually in early 1989 due to the pressures from the Solidarity leadership and the church — both pointing to the looming disasterand the strengthening position of reformists within the party. The Polish Army and the security forces, controlled by Jaruzelski and Kiszczak, had gradually moved from their position as 'the faithful arm of the Communist Party' to something approximating a 'third party' — doubtless a response to the mounting

\footnotetext{
1 Not before trying (unsuccessfully) to 'circumvent the Solidarity issue' in negotiations with Western creditors, and organising a showdown with the party hardliners during the stormy Plenum in January 1989, when the entire reformist party leadership, criticised for its conciliatory gestures towards the opposition, offered to resign.

2 Codogni (2009:254).
} 
political woes at home, liberal changes in Moscow and the climate of détente that made the prospects of a military solution unrealistic. Even the old hardliners started to realise that there were no alternatives to widely based negotiations.

The round table negotiations were conducted between the 'party-government side', representing both the ruling party-state apparatus and its military arm headed by General Jaruzelski (and represented by General Kiszczak), and the 'Solidarity-opposition side' that represented both the still illegal Solidarity, led by Lech Wałęsa, and dozens of oppositional political groups that formed during the 'lost decade'. Altogether 452 negotiators took part in the discussions conducted in the Viceroy Palace in Warsaw and 42 of the most senior representatives of both sides took part in more exclusive meetings conducted away from the limelight in Magdalenka, a small government resort near Warsaw. ${ }^{3}$

The main hope and expectation of the party-government side were defusing the growing social unrest (and, indeed, the protests subsided in April to the pre1989 levels) and gaining the support of the opposition for reforms of the Polish economy - a necessary condition for securing political stabilisation. The hope and major demand of the opposition were the re-legalisation of Solidarity and the recognition of all formerly banned oppositional groups. Solidarity leaders also hoped that the agreements would start a process of democratisation, and that this process would gradually erode authoritarian rule. Both sides agreed that the communist system needed to be overhauled, but while the party apparatus hoped for minor reforms that would not undermine the communist domination, the oppositional camp insisted on radical changes to the entire system. The price they were ready to pay was Solidarity's involvement in such painful changes (thus providing the necessary legitimacy and public support), and accepting gradualism, with some initial restrictions placed on the democratic process and full sovereignty aspirations vis-a-vis the Soviet Union.

After prolonged and stormy negotiations, an agreement was forged in early April 1989. Solidarity was formally recognised, together with its numerous organisational 'extensions' (rural, student, and so on). Moreover, the reforms were to take a clearly liberal-democratic direction, though with some temporary limitations. There were to be free and competitive parliamentary elections in June, but only to the upper house (Senate) and about one-third of the lower house (Sejm), with 65 per cent of seats in the Sejm to be initially (for the duration of the first Parliament) reserved for the party-government candidates. Moreover, the powers of the presidency, assumed to be in communist hands, were significantly strengthened-another safeguard for the nomenklatura. While the communist parliamentary majority was thus assured during the transition phase, the agreement included significant bonuses for the opposition:

3 Ibid.; Skórzyński (2009). 
elections to the upper house were completely free, thus allowing for the free articulation of democratic public opinion, and the introductory paragraph of the agreement stated that this was 'the beginning of the path to parliamentary democracy' - a politically pregnant phrase that proved prophetic.

Such an outcome was acceptable to both the Solidarity negotiators and the party-government team. The Solidarity side hoped to initiate the 'democratic dynamics' and gain some footing in the 'contract' parliament. The party leaders hoped to quell the unrest and involve the opposition in sharing responsibilities for the management of the collapsing Polish economy. Perhaps most importantly, the agreement gave the party apparatus a temporary assurance of tenure, even if they lost the electoral contest, and this reduced the unease of the nomenklatura.

But the agreement was a compromise, and compromises are seldom happy. The party leaders took the risk of legalising Solidarity and losing the electoral contest - the possibility they failed to anticipate-and Solidarity accepted the risk of losing their public support by collaborating with the discredited communists. ${ }^{4}$ Mindful of those risks, the participants in the round table adopted the strategy of 'openness without fanfare'; they invited the media to plenary debates, publicised the agreements, but kept the details of haggling and disagreements confidential, though not secret; the detailed minutes of negotiations were subsequently published. While many discussions occurred away from the media, mainly in order to protect the negotiators and increase their capacity to make compromises, all the important agreements - as well as disagreements - were summarised at open plenary sessions and ratified by the opposition leaders, including Lech Wałęsa and Solidarity's National Executive Commission (KKW). Most importantly, both sides also relied on the church's observers, who became both the guardians of integrity and arbiters in resolving disagreements. This informal sponsorship by the church, and warm support for the round table given by the Pope, reduced criticism and increased public trust.

Rather than an elite conspiracy - as some critics, such as the Kaczyński brothers, later alleged - the round table constituted a wise application of perhaps the most important social invention of the twentieth century: a negotiated elite pact paving the way for gradual and peaceful regime change. Such pacts were successfully forged in almost all reformed democracies: in Spain and Greece in the 1970s, in the Philippines in 1986, and in South Korea and Taiwan in the late 1980s. The Polish round table was an important variation of the elite-

4 In fact, the round table marked a deep split within Solidarity. The more radical factions - the 'Fighting Solidarity' of Kornel Morawiecki and the 'Working Group' of Andrzej Gwiazda and Anna Walentynowiczrefused to participate in the negotiations and condemned the round table as a 'pact with the devil'. The criticisms gained momentum with the installation (followed by the prompt demise) of the Olszewski government, and the ascendancy of the Kaczyński twins (the late Lech and Jarosław), first to the leadership positions in PiS, and subsequently to the presidency and premiership of Poland (Codogni 2009:Ch. 6; Skórzyński 2009:221-4). 
negotiated 'pacted transition' model ${ }^{5}$ that was subsequently applied - in a compacted form and on a much smaller scale - in Hungary (June-September 1989), Czechoslovakia (November 1989 and January 1990), Bulgaria (JanuaryApril 1990) and Romania (January-February 1990). Even when it was more a symbolic gesture than a real negotiation, as in the last two cases, the agreements underscored the willingness of the leaders to follow some restrained, orderly political competition - the essential precondition of democracy - and, perhaps most importantly, accept a peaceful and negotiated change of political regimes. ${ }^{6}$

The first, immediate outcome of the round table was the 'contract' elections in early June. The Solidarity camp started the campaign completely unpreparedinexperienced in conducting campaigns, under-resourced, relying on voluntary work and with only limited access to the mass media. Solidarity itself, although re-legalised, was weak, with only about one million members - a mere shadow of the 10 million-strong movement in 1981. The opposition was divided, with some dissenters criticising Wałęsa for his conciliatory strategy. The mass media was in communist hands, attacking 'Solidarity extremists'. Censorship was rife, using all pretexts to limit and distort the voice of the opposition. Intimidation of Solidarity campaigners and activists was widespread. Above all, Polish society was exhausted by the economic crisis and the daily struggle for survival in the climate of uncertainty and with empty shelves in the shops and hyper-inflation (more than 500 per cent in mid-1989). In the final days of the campaign, as Wałęsa recalls in his memoirs, the major challenge was just to convince people to vote. ${ }^{7}$

\section{High Noon ${ }^{8}$}

The Solidarity campaign was a grassroots improvisation. It involved 100000 activists, as well as prominent celebrities - Stevie Wonder, Jane Fonda, Yves Montand-and dozens of less-known supporters. The Citizens' Electoral Committee 'Solidarity' (formed in 1988 to coordinate the oppositional strategy) had little time - and no material means - for an elaborate strategy. It utilised volunteers to collect funds, print posters, distribute leaflets and, above all, paint the ubiquitous electoral graffiti, always in a recognisable 'Solidarity script'. On 8 May, the first issue of Gazeta Wyborcza (Election Gazette) appeared, edited

\footnotetext{
5 Linz and Stepan (1996:356).

6 As mentioned in Chapter 6, five years later, the round table model was applied in South Africa, and more recently in Georgia and Ukraine. It has been estimated that at the turn of the century more than one billion people around the world benefited from the successful application of the round table model, and from peaceful 'refolutions' that followed these applications.

7 Wałęsa (2008).

8 Reference to the most popular Solidarity electoral poster referring to the famous film High Noon, with Gary Cooper sporting the Solidarity badge.
} 
by a prominent dissident intellectual and Solidarity advisor, Adam Michnik. It was an instant hit and remains today the daily with the highest circulation in Poland. On the eve of the poll, the first issue of the Solidarity Weekly reappeared after seven years of suppression, edited by a leading Catholic intellectual and Solidarity advisor, Tadeusz Mazowiecki. The key element in the campaign, however, was Wałęsa's personal appeal. The charismatic Solidarity leader - the 1983 Nobel Peace Laureate and the most iconic opposition figure-proved the best electoral asset. The Solidarity candidates, invariably photographed with Lech Wałęsa, campaigned under the Obama-esque slogan 'We must win'. The communists and their supporters chose the slogan 'It is safer with us' — borrowed from an ad for condoms, according to the local joke.

The results of the election caught everyone by surprise. Ninety-nine of 100 Senate seats and all 161 contested lower house seats were taken by Solidarity candidates. Moreover, to the great embarrassment of the communist rulers, only two of the 35 communist officials on the 'reserved' (that is, uncontested) national list, who were running unopposed, received the required minimum 50 per cent of votes. Most of these seats had to be filled in the second round of elections (on 18 June). The turnout was relatively modest (63 per cent) in the first round, and very low in the second round (25 per cent) - doubtless a reflection of the widespread view that the second round aimed mainly to reduce the communists' embarrassment. The joy in the Solidarity camp was only temporarily dampened by the reports of the Tiananmen Square massacre on the very day of the poll- $-\mathrm{a}$ dramatic reminder of the communist parties' political toolbox.

The public enthusiasm was tempered by two questions: 'Will the communists respect the results?' and 'Was the election sufficiently democratic to give Solidarity a mandate to rule?' As to the former, the doubts were lifted when Jaruzelski acknowledged the results as 'the undeniable fact'. The communist leaders did not do it immediately, though, and this hesitation caused much concern and prompted Solidarity to make a number of concessions, including the quick filling of the 'national list' (seats reserved for the party officials) and publicly supporting Jaruzelski's candidacy for presidency. These conciliatory gestures, plus the firm position of the Catholic Church Episcopate, whose leaders reminded Jaruzelski that pacta sunt servanda, helped in the official 'recognition' of the election results.

As to the latter question, the doubts about Solidarity's mandate disappeared gradually. Although there were no doubts as to who had won the poll, party critics started to voice some procedural objections. But these were dismissed. To all observers, including the communist commentators, the June poll had provided a free and fair articulation of public preferences. The 'contract' restrictions, as it turned out, did not matter. Polish society spoke freely for the first time since 1947, and its voice was strong and clear. Thus, the elections 
turned free and democratic in their function and outcomes; they accurately reflected public opinion, and they effectively put an end to the communist myth of wide public support. Solidarity got a mandate to rule.

\section{The Aftermath}

The commentators of the time talked about three political miracles: the communists lost, Solidarity won, and-most miraculously-the communists openly acknowledged their loss and Solidarity's victory. It was the Communist Party's acceptance of defeat that was most unexpected and miraculous.

Why did the party leaders agree to honour the deal? There were four good reasons. First and foremost, Solidarity's electoral victory was undeniablestark and crushing, leaving no doubt as to the underlying public sentiment. Second, there was the 'Gorbachev factor' and the 'new climate of détente' both conducive to democratic reforms. The Soviet liberal permissiveness made democratic reforms acceptable among many apparatchiks used to following the directives from Moscow. Third, the Polish party leadership was desperate to avoid social unrest. They needed social stability, wider public consent and, above all, a credible political partner to share responsibilities for governing. Only the negotiated democratic path could provide those. Fourth, by mid-1989, Solidarity had two important partners-supporters who strengthened its hand: internally it was the Catholic Church (backed by the immensely influential voice of the Pope); externally, it was Hungary, which followed the reformist path with new vigour.

For Solidarity and the opposition, the election outcome was a dream victory, but also a source of considerable problems. The unanticipated strength of public backing, while greeted with relief by Solidarity supporters, generated some anxiety among the leaders, who became aware of escalating public expectations, new responsibilities, unpredictable communist reactions at home and, last but not least, responses in Moscow (which, it must be remembered, still kept more than 60000 Soviet troops in Poland). It must also be remembered that the elections happened in the shadow of the Tiananmen Square massacre and daily reminders that communists still controlled the government, the army and the police. The caution with which Wałęsa and Mazowiecki acted in June-August reflected these genuine concerns.

In the Communist Party headquarters, the election results were received with shock. It was a complete rout that left the apparatchiks shell-shocked, but not humbled. The opposition 'does not know what to do', commented Kiszczak. 'This will have serious repercussion[s] in the entire [communist] bloc', threatened the 
new party First Secretary, Mieczysław Rakowski. ${ }^{9}$ They desperately tried to save face and influence by prolonging the negotiations on the formation of the new government. Initially, the communists insisted on filling both the president and the prime minister positions (with Jaruzelski and Kiszczak respectively), and claimed all the strategic ministries: defence, security and foreign affairs. When politely refused, they attempted to renege on the round table agreement - only to be reminded by Solidarity and the Catholic Church Episcopate that pacta sunt servanda. Finally, they also considered 'a new variant of martial law', but were discouraged by Gorbachev. ${ }^{10}$

Reactions outside Poland were muted. As Bronisław Geremek recalls, Western governments worried about the impact of the electoral victory on Gorbachev, and warned Solidarity against 'triumphalism'. ${ }^{11}$ But their concerns diminished when the Soviet leadership endorsed both the election results and the prospect of a Solidarity-led government, floated by Michnik in early July. ${ }^{12}$ In contrast, the hardline Communist Party establishment howled. Erich Honecker banned Polish newspapers and started a hostile campaign against Polish guest workers in East Germany. The Romanian Communist Party sent an open letter to Polish comrades warning them against 'capitulation'. The Czechoslovak communists warned darkly about 'destabilisation' of the bloc.

Solidarity's response was cautious. They confirmed their respect for 'Poland's international obligations' (read: the Warsaw Pact), and promptly engineered the reassuring presidential appointment of General Jaruzelski (by one vote only). But they refused to form a 'grand coalition' government under the communist leadership. Wałęsa insisted that Solidarity either formed its own government, with communists holding a handful of strategic posts, or it went into opposition. ${ }^{13}$ Following further negotiations, the first non-communist Polish government since 1947 was formed, headed by a Catholic intellectual and Solidarity advisor, Tadeusz Mazowiecki. The slogan popularised in early July by Solidarity's Gazeta Wyborcza - 'Your president, our premier' — had proven prophetic.

This started mass defections from the Communist Party. While the party was melting, their complacent 'partners' - the Peasant Party and the Democratic

9 Skórzyński (2009:357).

10 According to Ash (2009b), the last Communist Party boss in Poland, Mieczysław Rakowski, sounded out Gorbachev on the possibility of 'a new variant of martial law' in August 1989. Needless to say, Gorbachev responded that it was impossible.

11 Geremek and Żakowski (1990:190-4).

12 In early July 1989, after Michnik published an article titled 'Your president, our premier', proposing a Solidarity-led government, one of Gorbachev's advisors, Vadim Zagladin, stated in Paris: 'This decision [of forming a Solidarity government] is the internal issue of our friends. We shall maintain relations with any government elected in Poland. We are happy with the course of the process of democratisation in this country [Poland], and I would not call the situation in Poland "critical"" (quoted in Codogni 2009:274).

13 Skórzyński (2009:374) and Wałęsa (1991:151, 2008:298). 
Party - started to talk about a new partnership with the victors. This opened the way for a new Solidarity-Peasant Party-Democratic Party alliance in the Parliament, and the formation of the Solidarity-led government of Tadeusz Mazowiecki.

By the time the Mazowiecki government was sworn in on 12 September, Solidarity was formulating the core of its program. It included constitutional reforms ending the communist monopolies, strengthening civil liberties, widening democratisation to local government, and strengthening the divisions of power, as well as a plan of economic stabilisation, privatisation and market reforms (known as the 'Balcerowicz Plan') constructed since 1986 by a group of young economists from the Warsaw SGPiS, led by Leszek Balcerowicz, who become Deputy Premier and Minister of Finance. Moreover, this programand the mode of its implementation through the negotiated change of regimebecame a model embraced by the oppositional forces all over Eastern Europe. This was the essence of the Breakthrough.

\section{The Burden of Transition}

The Breakthrough achieved much more than democratisation. It also created a strong agent of reform: the oppositional government protected by the 'political umbrella' extended by Solidarity. Such a government-capable not only of reforms, but also of systemic transition - was possible only because of the profound changes that occurred in the Solidarity camp. Under the electoral imperative, Solidarity improved its organisation and discipline. Moreover, the unexpected victory prompted the leadership to clarify its structure and crystallise its program. While at the beginning of 1989 Solidarity still formed an amorphous protest movement, by the time Mazowiecki formed the first opposition-led government, Solidarity also spawned a strong pro-reformist parliamentary organisation, as well as a disciplined central union. The government proved not only coherent and competent, but also determined to start an immediate systemic transition. The organised union movement, in turn, extended a 'protective umbrella' over the painful process of transformation. The radicalism of Polish transition - the fact that they embarked on the process of systemic transformations almost immediately after forming a government - was due largely to this profound organisational change in the reformist camp. This was an essential aspect of the Breakthrough.

To become an effective transformative force - the first such force in Eastern Europe - Solidarity also had to change the sentiments of its supporters. It had to evolve from a mass movement unified by shared moral opposition to communist rule into a trade union cum quasi-political party, unified by the 
vision of change. ${ }^{14}$ It had to forge a program of transformation that could change the party-state into a nation-state, build democratic institutions and stabilise the economy. In short, it had to move from opposition to affirmation, from value declarations to programmatic statements, from moral 'anti-politics' to sober and responsible transformative politics - and gain public approval for these dramatic changes. It succeeded, and most of the shift in popular orientations occurred between February and September 1989. At the time the first Solidarity government was formulating the plan of transition, the majority of supporters stood behind it. ${ }^{15}$ Poland was entering the stage of transformation into postcommunism. ${ }^{16}$

Perhaps the least appreciated, yet most crucial achievement of the Breakthrough was the successful engagement of pro-reformist communists in the democratic process. Transforming them from enemies into rivals, drawing them into the 'democratic tent', and obliging them to play the democratic political gamewhich they did, reluctantly - was a major success of the Breakthrough period. And this also proved the key condition of democratic consolidation. Without this engagement of ex-communists at the elite level, the process of democratisation would not continue-as amply demonstrated in Bulgaria, Romania and Yugoslavia.

As anticipated by opposition leaders, the democratic game initiated during the Breakthrough proved self-perpetuating, robust and dynamic. The political spectrum was widened, civic activism extended to all organisations, and demands for civil and political rights gradually morphed into expectations of full democracy and sovereignty. All of these changes - largely unanticipated even by the most optimistic forecasters - justify our label 'Breakthrough'. It highlights not only an objective transition from reform to systemic transformation, but also a widespread subjective sense of a break with the past, a new beginning that started to dawn on the mass public only when the new government started to outline plans for market, legal-constitutional and administrative changes. In

14 In order to do that, Solidarity also had to overcome its internal divisions. Forming a single electoral list of Civic Electoral Committee Solidarność was a good starting point. Presenting a common front was, however, a big challenge, especially when one of the promoted goals was political pluralism. In that respect, Lech Wałęsa proved a great asset - as well as a liability. He campaigned tirelessly during the election campaign using his charisma and oratory skills. But he also endlessly irritated his advisers by playing solo and making arbitrary decisions. Exasperated colleagues in the Civic Committee saw him as a political maverick, incapable of disciplined teamwork. In the end, however, his political instincts proved stronger than his narcissistic streak. But he refused to run for presidency, turned down the offer to head the Solidarity government, and, towards the end of 1989, started a drive towards 'pluralism' by distancing the Solidarity trade union from the government and criticising Mazowiecki.

15 Mazowiecki's government initially enjoyed very high public support of more than 70 per cent. This support dwindled in 1990, due partly to painful economic reforms, and partly as a result of growing criticism by Lech Wałęsa, who started, at the end of 1989, an infamous 'war at the top'.

16 Holmes (1997:141-69) and Linz and Stepan (1996:270-2). 
early October, a popular Polish actress, Joanna Szczepkowska, could announce on a Polish TV news program: 'Ladies and Gentlemen, communism ended in Poland on 4 June 1989.' ${ }^{\prime 7}$ If she erred, it was only by less than four months.

\section{The External Impact}

The events in Poland had an immediate 'refolutionary' impact on her neighbours. Hungary hardly needed any prompting; the party reformists there were already dismantling the partocratic system. The closest neighbours, however, Czechoslovakia and East Germany, remained frozen, though already infected by the virus of freedom spreading from Poland and Hungary. In August 1989, on the anniversary of the Warsaw Pact suppression of the Prague Spring, there were demonstrations in Poland in solidarity with a handful of Czechoslovak dissidents who publicly condemned the 1968 invasion. In summer 1989, the newly elected Solidarity parliamentarians used their diplomatic immunity to visit Václav Havel, recently released from jail. Havel himself acknowledged the great impact of Solidarity's victory in creating a new political 'thaw' ${ }^{18}$

The response in East Germany was less direct. Erik Honecker, scared by the spread of what he called a 'Polish disease', virtually sealed the Polish-German border in summer 1989. He also started an anti-Polish campaign in the press accompanied by expulsions of Polish workers. This did not stem the flow of East German refugees escaping en masse through Poland and Czechoslovakia to Hungary, where they were allowed (from mid-September) to cross the border to Austria. Polish authorities, in turn, helped them to reach the West German Embassy and negotiated their transfer to West Germany by the sealed 'freedom trains'.

All these developments, and the subsequent governmental reforms proposed by the Solidarity government, became, almost overnight, headline news. When suppressed by censorship in neighbouring countries, they spread through the press, on radio and television. Many Czechs could listen to Polish, West German and Austrian broadcasts. Most Slovaks, who could understand Polish and Russian, listened to radio programs transmitted from Warsaw and Moscow. Most East Germans had no difficulties in accessing the news broadcast from

17 Geremek and Żakowski (1990:268).

18 "'Solidarity" met with a response in Czechoslovakia, though the change here had many causes...When the Round Table talks started [in Poland], and some of our friends became MPs, while at our place nothing was changing yet, the Polish example was naturally a support for us. I remember when Adam Michnik with two friends visited me at Hradeczek [Havel's flat in Prague] and our police could not stop them, because they had the diplomatic status. When I was jailed again in 1989, my plays were already staged in Warsaw...I also remember that I wrote to then Polish Prime Minister, Tadeusz Mazowiecki, about political prisoners in Czechoslovakia, and I got a reply! This was the first Prime Minister who replied to my letter.' Quoted in Wałęsa (2008:326). 
West Germany. They monitored the developments in Poland with growing hope and anticipation. It became clear to them that the Mazowiecki government was starting a bold systemic transition to liberal-democratic law, polity and a market economy. This was a radical transcendence of perestroika and glasnost, which were now superseded by demokratizacya and svoboda.

Mazowiecki's program impressed (and scared!) Poland's communist neighbours because it was both radical and comprehensive. It covered the entire spectrum of legal-constitutional, economic, social and political-administrative reforms, all backed by Solidarity and unopposed by the communists. This endorsement of the systemic change by the communists - the development that the Polish government shared with the reformist Hungarian regime - was most surprising and demoralising to the Eastern European hardliners. As expected, the programand the accompanying strategy of gradual, negotiated, peaceful and consensual implementation - soon became the guiding model for all oppositional programs throughout the region.

The Polish model was 'safe' in many ways. First, it helped in avoiding the conflict and bloodshed that often accompanies changes of regime. Second, the sequencing of Polish reforms - democratisation first, full sovereignty laterhelped in avoiding violence and nationalistic pathologies that could lead Eastern Europe into the 'Serbian trap', whereby the energy of the reformers was channeled into the 'national liberation' path that frequently degenerated into violent and illiberal nationalism involving ethnic cleansing and territorial vindications. The nationalistic movements that erupted in southern regions of Eastern Europe did not follow the Polish path, and they resulted in frequent reinstallment in power of communist nationalists, such as Milosevic. The Polish model, in contrast, pre-empted the mobilisation of nationalistic movements by insisting on the priority of liberal democratic reforms. Third, the Polish model proved effective and popular because it did not undermine Gorbachev and had not closed the window of opportunity for further liberalising changes in the Soviet Union. Concerns about 'keeping the Soviet window of opportunity open' were behind the Solidarity leaders' strategic decision to keep General Jaruzelski, a self-declared Gorbachevite, in the presidential position. Anti-Soviet sentiments were tempered, and both Mazowiecki and Wałęsa maintained constant contacts with Moscow (as well as with Washington, Bonn, Paris and London). ${ }^{19}$ Fourth, the Polish path proved effective by combining an elite-negotiated political pact with a grassroots mobilisation of support. It was a fortuitous political novum heralding prompt and safe democratisation. Mazowiecki's program of change was firmly backed by Solidarity as well as being endorsed by the majority of the population, including reformist communists. This guaranteed the continuity and therefore the ultimate success of the transformation. 


\section{Conclusion}

The Polish Breakthrough had changed not only the pace, but also the general direction of Eastern European changes. Glasnost was radicalised into democratisation; perestroika turned into transformation. Moreover, from September 1989, both the socio-political and the socioeconomic reforms started to evolve in the liberal-democratic direction - and beyond the boundaries of the communist system. They led in the Western European direction. The Solidarity government insisted on liberal parliamentary democratisation, emulating the familiar Western European models. The importance of this insistence might not be obvious today, but at that time, it was crucial in directing the transformations on the civic and liberal-democratic track, or, as Geremek put it, the track 'back to Europe'. But it was by no means the only program, the only choice for the reformers. From the very start, the Polish model competed with a less radical program of limited reforms aimed at 'democratising the existing socialism' particularly popular in Czechoslovakia and among left-leaning dissenters in East Germany. ${ }^{20}$ Various versions of this largely utopian 'socialism with a human face' and the accompanying versions of 'socialist', 'worker', 'Christian' and 'third way' democracy were floated by dissident intellectuals, especially in East Germany, Hungary and Czechoslovakia. ${ }^{21}$ The Polish opposition leaders, in contrast, insisted from the start that the reforms had to go 'back to Europe' - that is, in a liberal-democratic direction. Where this path of liberal democratisation was adopted, the transformations progressed smoothly and resulted in a swift European unification.

It is also worth pointing out that the Breakthrough benefited from, and reinforced, the process of globalisation. Eastern Europe in 1989 was already a 'global village' where ideas started to circulate relatively freely. They spread through the mass media, as well as personal contacts among opposition activists. Informational isolation and censorship - the key tools of authoritarian and totalitarian regimes - were already crumbling. East Germans could listen to West German radio and television; Czechs and Slovaks had access to Polish (which they could understand) and Austrian broadcasts; Romanians could watch Moldovan programs (in Romanian), and those in Transylvania could listen to Hungarian radio; most of Bulgaria was covered by Soviet broadcasts increasingly popular at the time of glasnost. The channels of information easily transformed into the channels of institutional diffusion, especially when this diffusion was intentional.

20 It should also be remembered that it was the reformist-socialists, such as Pozsgay in Hungary and Dubcek in Czechoslovakia, who directed the first wave of reforms, and they were not keen on the emulation of Western parliamentary democracy. There were also political opportunists, such as Adamec, Krentz and Modrow, who were cheered at public meetings in Prague and Berlin in November-December 1989.

21 Judt (2005:615-16). 
This is why the 'Polish disease' could spread fast, prompting the acceleration of change in the region. The Hungarian round table - more symbolic than real in the absence of intransigent communists - came later, but it led to very prompt democratisation and liberalisation. The hardliners Erich Honecker and Gustav Husak managed to stem the spread of the 'Polish disease' until late 1989. In spite of Gorbachev's warning, Honecker resisted reforms to the bitter end, and he contemplated a Tiananmen-like suppression of dissent, as advised by the Chinese delegation that visited Berlin on 10 October. But he was promptly deposed by the party reformists, who, in turn, were swept away by mass public demonstrations triggered mainly by the opening of the Hungarian and Polish borders. In early November, the Berlin Wall collapsed, and, in December, the East German Communist Party was dissolved - reborn as Democratic Socialists. A year later, East Germany was absorbed by her West German neighbour — with the strong support of the public and reluctant approval of Moscow (prompted by a massive $\$ 71$ billion in aid). In late October, the mass protests spilled into Prague, which had remained politically 'frozen' since the 1968 'normalisation'. After a short - and largely symbolic — round table in late November (and slightly longer negotiations in January), an unstable 'coalition government' was formed, and, in December, Václav Havel was sworn in as President. By the end of the year, even the longest-serving and the most entrenched communist regimes, in Bulgaria and Romania, collapsed. Todor Zhivkov was deposed a day after the breaching of the Berlin Wall (10 November), and the Ceausescus were arrested and hastily executed on Christmas Day. In January 1990, both countries started their-again, largely symbolic_-round tables. ${ }^{22}$

This acceleration of change was remarkable. There were, no doubt, some internal and nation-specific causes that energised the opposition in each of the countries, but even if this was the case, the Polish Breakthrough was the starter's signal. It turned a march into a sprint and triggered a sort of national competition; who would be first to shed the communist monopolies? Who would lead the constitutional reforms; who would first declare full independence? This competition and acceleration were reflected not only in the pent-up public frustrations, but also in the availability of the successfully tested 'Polish track'. As Timothy G. Ash noted, 'what took ten years in Poland, took ten months in Hungary, ten weeks in East Germany, and ten days in Czechoslovakia' ${ }^{23}$ 


\section{Bibliography}

Ash, T. G. 1983. The Polish Revolution: Solidarity 1980-82, Jonathan Cape, London.

Ash, T. G. 1990. Wiosna Obywateli: Rewolucja 1989 widziana w Warszawie, Budapeszcie, Berlinie i Pradze [The Springtime of the Peoples: Revolution of 1989 as seen from Warsaw, Budapest, Berlin and Prague], Polonia, Warszawa.

Ash, T. G. 2009a. '1989!', New York Review of Books, vol. 56, no. 17 (5 November).

Ash, T. G. 2009b. 'Velvet revolution: the prospects', New York Review of Books, vol. 56, no. 19 (3 December).

Beres, W. and Burnetko, K. 2009. Nasza historia: 20 lat RP [Our History: 20 years of Polish Republic], Świat Ksiażki, Warszawa.

Codogni, P. 2009. Okragły Stól, czyli Polski Rubikon [Round Table or the Polish Rubicon], Collegium Civitas/Kroszyński Media, Warszawa.

Engel, J. A. (ed.) 2009. The Fall of the Berlin Wall: The revolutionary legacy of 1989, Oxford University Press, Oxford.

Geremek, B. and Żakowski, J. 1990. Rok 1989: Geremek Opowiada, Żakowski Pyta [1989. Geremek Talks, Żakowski Asks], Plejada, Warszawa.

Holmes, L. 1997. Post-Communism: An introduction, Polity, Cambridge.

Judt, T. 2005. Postwar: A history of Europe since 1945, Penguin, New York.

Linz, J. J. and Stepan, A. 1996. Problems of Democratic Transition and Consolidation, The Johns Hopkins University Press, Baltimore and London.

Skórzyński, J. 2009. Rewolucja Okragłego Stołu [The Round Table Revolution], Wydawnictwo Znak, Kraków.

Wałęsa, L. 1991. Droga do Wolności [Road to Freedom], Świat Ksiażki, Warszawa.

Wałęsa, L. 2008. Droga do Prawdy [Road to the Truth], Świat Ksiażki, Warszawa. 